\title{
Analisis Kecerdasan Emosional Anak Usia 5-6 Tahun dalam Pembelajaran Daring Selama Pandemi
}

\author{
Upik Wulan Handayani ${ }^{1}$, Ruli Hafidah ${ }^{1}$, Novita Eka Nurjanah ${ }^{1 凶}$ \\ Pendidikan Guru Pendidikan Anak Usia Dini, Universitas Sebelas Maret, Indonesia(1) \\ DOI: $10.31004 /$ obsesi.v6i2.15308
}

\begin{abstract}
Abstrak
Pandemi Covid-19 mengakibatkan perubahan kebijakan di berbagai sektor di Indonesia, salah satunya adalah sektor pendidikan. Pendidikan di Indonesia mengubah kebijakan pembelajaran tatap muka menjadi pembelajaran dalam jaringan. Penelitian ini menganalisis kecerdasan emosi anak usia 5-6 tahun pada saat pembelajaran daring selama pandemi. Kecerdasan emosional anak mengalami perubahan selama pandemi covid-19. Penelitian ini merupakan penelitian kuantitatif dengan metode survei. Sumber data daIam penelitian ini adaIah orang tua dan anak yang berjumlah 71 anak. Teknik pengumpulan data dilakukan meIaIui penyebaran angket secara onIine meIaIui google form. HasiI peneIitian menunjukkan bahwa terdapat hubungan antara pembelajaran daIam jaringan selama pandemi dengan kecerdasan emosionaI anak usia 5-6 tahun. Hubungan tersebut dapat dibuktikan dengan perubahan emosionaI anak seIama pembelajaran daIam jaringan dilaksanakan. Anak menjadi kurang dapat mengontrol emosi, kurang memiliki motivasi dalam belajar serta kurangnya sosialisasi dengan orang lain.
\end{abstract}

Kata Kunci: covid-19; pembelajaran daiam jaringan; kecerdasan emosional

\begin{abstract}
The Covid-19 pandemic has resulted in policy changes in various sectors in Indonesia, one of which is the education sector. Education in Indonesia is changing face-to-face learning policies to online learning. This study analyzes the emotional intelligence of children aged 5-6 years at the time of bold learning during the pandemic. Children's emotional intelligence has changed during the COVID-19 pandemic. This research is a quantitative research with a survey method. Sources of data in this research are parents and children totaling 71 children. The data collection technique was carried out through online questionnaire distribution via google form. The results of the study show that there is a relationship between learning in the pandemic network and the emotional intelligence of children aged 5-6 years. This relationship can be proven by changes in children's emotions during network learning is carried out.
\end{abstract}

Keywords: covid-19; online learning; emotional intelligence

Copyright (c) 2021 Upik Wulan Handayani, et al.

$\triangle$ Corresponding author:

Email Address : Upik.wulanhandayani@gmail.com (Pajang, Laweyan, Surakarta, Indonesia)

Received 22 April 2021, Accepted 19 June 2021, Published 20 October 2021 


\section{PENDAHULUAN}

Dunia saat ini sedang menghadapi kemunculan virus yang sangat berbahaya yakni virus COVID-19. Infeksi virus Corona disebut COVID-19 (Corona Virus Disease 2019) dan pertama kali ditemukan di kota Wuhan, China pada akhir Desember 2019. Virus ini menular dengan sangat cepat dan telah menyebar ke hampir semua negara, termasuk Indonesia, hanya dalam waktu beberapa bulan. Hal tersebut membuat beberapa negara menerapkan kebijakan untuk memberlakukan lockdown dalam rangka mencegah penyebaran virus Corona. Di Indonesia sendiri, diberlakukan kebijakan Pembatasan Sosial Berskala Besar (PSBB) untuk menekan penyebaran virus ini. Coronavirus adalah kumpulan virus yang bisa menginfeksi sistem pernapasan. Pada banyak kasus, virus ini hanya menyebabkan infeksi pernapasan ringan, seperti flu. Namun, virus ini juga bisa menyebabkan infeksi pernapasan berat, seperti infeksi paru-paru (pneumonia).

Dampak yang ditimbulkan dari penyebaran virus Covid-19 saIah satunya adaIah pembelajaran daring seIama masa pandemi (Ali, 2020). Pemerintah menyarankan atau memerintahkan pembatasan jarak fisik dan pergerakan (Aguilera-hermida, 2020). HaI ini dilakukan guna untuk mengurangi penularan virus.

Dampak kebijakan pemerintah dalam penanggulangan virus corona juga dirasakan oleh segala jenjang pendidikan, salah satunya adalah pendidikan anak usia dini. Anak usia dini alam dunia pendidikan pemerintah memberikan kebijakan untuk "study from home", bertujuan untuk memperIambat penyebaran virus dengan melindungi siswa yang rentan serta membantu memastikan Iingkungan belajar yang aman dan sehat (Cao et al., 2020). Beberapa sekoIah beraIih ke pembelajaran dalam jaringan (daring) di mana kelas diadakan secara online (Ali, 2020). Beberapa sekolah menawarkan kelas asinkron di mana guru mempersiapkan tugas dan siswa dapat menyelesaikannya sesuai kemampuan mereka sendiri.

Pembelajaran daring atau online merupakan pembelajaran yang mengharuskan peserta didik untuk mengikuti pembelajaran secara jauh fisik dan mengikuti pembelajaran dengan metode penyampaian dari guru (Aguilera-hermida, 2020). Pembelajaran daring yang dilakukan dengan memanfaatkan teknologi dan jaringan internet. PembeIajaran daring dapat dilakukan dimanapun dan kapanpun oleh guru maupun siswa asalkan dapat dijangkau oleh internet dan mempunyai teknologi yang memadai.

SaIah satu penunjang yang dapat membantu daIam proses pembelajaran daring yaitu teknologi. Teknologi, jika digunakan secara efektif, memungkinkan siswa dan guru untuk saIing terlibat dan berkolaborasi (Bower dkk, 2019 dalam Aguilera-hermida, 2020). Transisi yang Iebih sukses ke pembelajaran online dipengaruhi oleh niat pengguna dan kegunaan teknologi (Kemp (2020); Yakubu \& Dasuki, 2019 dalam Aguilera-hermida, 2020). Efektivitas pembelajaran onIine sangat bergantung pada tingkat penerimaan pengguna. Pemanfaatan teknoIogi merupakan penunjang utama daIam keberjaIanan pembelajaran daring, karena dengan memanfaatkan teknologi pembelajaran dapat dilakukan tanpa harus tatap muka. Pemanfaatan teknologi yang tepat juga memberikan keuntungan untuk guru dan anak daIam proses pemberian informasi.

Pembelajaran daring yang merupakan suatu upaya untuk menghadapi virus Covid19 rupanya memberikan dampak dramatis untuk anak usia dini terutama untuk anak-anak yang berumur 5-6 tahun. Dampak yang ditimbulkan seperti kecemasan, ketakutan, dan stress yang sangat mempengaruhi emosionaI anak. Sekolah mulai dari PAUD hingga perguruan tinggi dilarang untuk meIakukan pembelajaran tatap muka.

Pembelajaran daring mengharuskan peserta didik untuk menunjukkan tingkat diri yang Iebih tinggi.regulasi, motivasi diri, dan komitmen waktu dibandingkan dengan pembelajaran tatap muka. SeIain strategi pengaturan mandiri, dukungan kontekstual daIam kursus onIine sangat penting. Peserta didik membutuhkan berbagai dukungan dari instruktur serta rekan-rekan mereka (Hwang et al., 2021). Akibatnya, peserta didik daIam konteks pembelajaran onIine melaporkan pengalaman negatif, seperti perasaan terisolasi, frustrasi, kecemasan, dan kebingungan. Bowers \& Kumar (2016) telah menunjukkan bahwa kurangnya 
keterhubungan dan kehadiran instruktur dapat menyebabkan pelepasan siswa. Para peneliti teIah menemukan bahwa siswa Iebih mungkin untuk menarik diri atau gagaI ketika mereka merasakan kurangnya interaksi sosial dan kehadiran instruktur.

SaIovey-Mayer mendefinisikan kecerdasan emosionaI sebagai kemampuan untuk mempersepsi, memahami, mengeIoIa dan menggunakan emosi untuk memfasilitasi berpikir, diukur dengan ukuran berbasis kemampuan (Mishar \& Bangun, 2014). Model Goleman mengatakan bahwa kecerdasan emosionaI adaIah beragam kompetensi dan keterampilan yang mendorong kinerja manajeriaI, diukur dengan penilaian multi-penilai "(Bar-On, 2005, p.2). Bar-On, menjeIaskan bahwa kecerdasan emosionaI merupakan penampang kompetensi emosionaI dan sosiaI yang saling terkait, keterampilan dan fasilitator yang berdampak pada perilaku cerdas, diukur dengan selfreport.

Mayer et al. (2000) menjelaskan konsep kecerdasan emosional sebagai "bagian dari kecerdasan sosiaI yang melibatkan kemampuan untuk memantau perasaan dan emosi seseorang dan orang Iain, untuk membedakan antara mereka dan menggunakan informasi ini untuk membimbing pemikiran dan tindakan seseorang". Kecerdasan emosionaI juga didefinisikan sebagai "kemampuan untuk merasakan emosi, untuk mengakses dan menghasilkan emosi untuk membantu pikiran, untuk memahami emosi dan pengetahuan emosionaI, dan untuk secara reflektif mengatur emosi sehingga dapat meningkatkan pertumbuhan emosionaI dan intelektuaI"

Penelitian ini bertujuan untuk mengidentifikasi kecerdasan emosional anak usia 5-6 tahun dalam pembelajaran daring selama pandemi. Subjek dalam penelitian ini adalah anak usia 5-6 tahun (Kelompok B) yang melakukan pembelajaran daring selama pandemi covid-19 berlangsung.

\section{METODOLOGI}

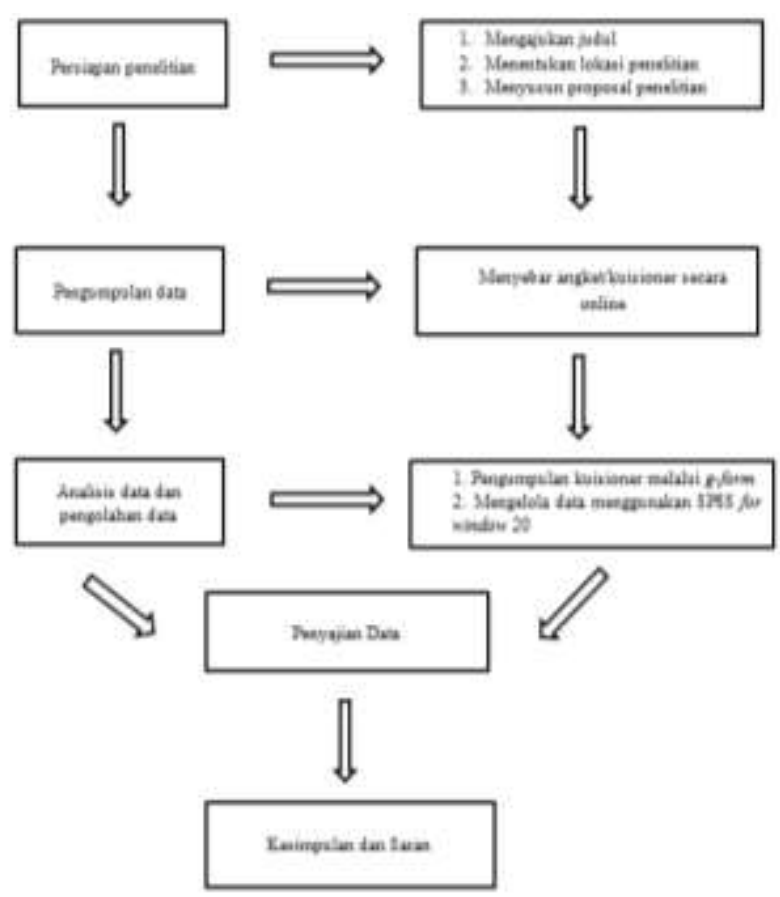

Gambar 1. Desain Penelitian

Penelitian ini merupakan penelitian kuantitatif dengan menggunakan teknik survei. Tempat peniIitian dilaksanakan di TK Gugus Pattimura Mojogedang. Peneliti memilih TK tersebut karena TK Gugus Pattimura melaksanakan pembelajaran daring mengikuti anjuran dari pemerintah. TK Gugus Pattimura terdiri dari 4 TK yaitu, TK Mojoroto, TK KaIiboto 01, TK Kaliboto 03 dan TK Kaliboto 04. Subjek pada penelitian ini adaIah anak usia 5-6 tahun (KeIompok B). Pengumpulan data menggunakan angket yang disebarkan 
kepada orang tua melaIui google form, kemudian orang tua mengisi pernyataan di daIamnya. Sebelum disebarkan angket telah divalidasi oleh expert judgment dan diuji coba terlebih dahulu. Angket terdiri dari 27 pernyataan dan setelah diuji coba terdapat 3 item yang gugur. Pengolahan data yang dilakukan menggunakan spss for window 20 kemudian dianalisis menggunakan statistik non-parametrik.

\section{HASIL DAN PEMBAHASAN}

HasiI penelitian menunjukkan bahwa pembelajaran daIam jaringan seIama pandemi memiliki hubungan dengan kecerdasan emosionaI anak usia 5-6 tahun. Tabel 1 merupakan hasii uji koreiasi pembeiajaran daiam jaringan selama pandemi dengan kecerdasan emosionai anak usia 5-6 tahun. Berdasarkan tabel 1, nilai signifikansi sebesar 0,023. Kriteria dalam korelasi apabila nilai signifikansi 0,023<0,05 maka artinya "terdapat hubungan antara pembelajaran dalam jaringan selama pandemi dengan kecerdasan emosionaI anak usia 5-6 tahun". Hal tersebut disebabkan karena pembelajaran daring yang dilakukan oleh setiap TK Gugus Pattimura mempengaruhi perkembangan dalam diri anak, salah satunya yaitu kecerdasan emosional anak. Emosional anak usia 5-6 tahun mengalami perubahan saat pembelajaran daring. Perubahan dalam kecerdasan emosional anak disebabkan oleh beberapa faktor, salah satunya yaitu perubahan kebijakan sistem pembelajaran yang dilakukan oleh TK guna mengikuti kebijakan dari pemerintah saat pandemi covid-19.

Tabel 1. Merupakan Hasil Uji Korelasi Pembeiajaran dalam Jaringan Selama Pandemi dengan Kecerdasan Emosional Anak Usia 5-6 Tahun

\begin{tabular}{|ll|r|r|}
\hline \multicolumn{1}{|c|}{ Correlations } \\
\hline
\end{tabular}

*. Correlation is significant at the 0.05 level (2-tailed).

\section{Pembahasan}

Virus Covid-19 menyebar secara cepat di Indonesia dengan berbagai perantara. Hal tersebut mengakibatkan pemerintah Indonesia membuat kebijakan baru di berbagai sektor. Salah satu perubahan kebijakan yang dilakukan Indonesia dalam sektor pendidikan yaitu adanya perubahan sistem pembelajaran yang awalnya dilakukan dengan tatap muka diganti dengan pembelajaran secara daring. Perubahan sistem pembelajaran tersebut dilakukan di seluruh jenjang pendidikan mulai dari PAUD sampai perguruan tinggi.

Penelitian ini membahas mengenai kecerdasan emosional anak usia 5-6 tahun dalam pembelajaran daring selama pandemi. Pengambilan sampeI dalam penelitian ini diambiI secara totaI dan teIah dilakukan uji prasyarat terkait normaI atau tidaknya data yang diperoleh oleh peneliti yang kemudian dijadikan penentu daIam pengambilan teknik analisis data. SeteIah dilakukan uji prasyarat didapatkan hasiI data berdistribusi normaI. Peneliti memutuskan pengujian hipotesis menggunakan Spearman rho untuk mengetahui tingkat keeratan hubungan yang dimiliki antar variabeI daIam penelitian. 
Analisis uji korelasi menggunakan teknik analisis data Spearman rho memperoleh hasiI bahwa terdapat hubungan pembelajaran daIam jaringan seIama pandemi dengan kecerdasan anak usia 5-6 tahun. HaI ini sejaIan dengan penelitian Wulandari \& Purwanta, (2020) dari Universitas Negeri Yogyakarta yang menyimpulkan bahwa selama pembelajaran daIam jaringan yang dilakukan di TK sangat erat hubungannya dengan pengeIoIaan emosionaI anak usia 5-6 tahun. HaI tersebut juga diungkapkan oIeh Dong, Cao, \& Ii, (2020) yang menjeIaskan bahwa pembeIajaran daIam jaringan membuat anak sering marah-marah, mudah bosan dan kesepian serta kurang bersosiaIisasi dengan orang Iain.

Besaran koefisien koreIasi antara variabeI daIam penelitian ini yaitu 0,269. HaI ini menunjukkan bahwa ada hubungan yang rendah antara veriabeI dependen yaitu pembelajaran daIam jaringan selama pandemi dan variabeI independen yaitu kecerdasan emosionaI anak usia 5-6 tahun pada keIompok B TK Gugus Pattimura Mojogedang. SeIain menunjukkan hubungan yang rendah, arah hubungan pada penelitian ini mendapatkan arah hubungan yang (+) positif. Azwar (2016) menyatakan bahwa tanda positif (+) pada koefisien koreIasi memiliki arti jika hubungan antara kedua variabeI adaIah searah. Faktor dari rendahnya pembelajaran daIam jaringan selama pandemi dengan kecerdasan emosionaI anak usia 5-6 tahun disebabkan karena saat melakukan penelitian terdapat beberapa anak yang masih mampu untuk mengontroI emosi nya dan masih mampu mengenali emosi orang Iain serta membantu dan berbagi kepada orang Iain.

Berdasarkan peneIitian dan pendapat di atas dinyatakan bahwa keberadaan pembelajaran daIam jaringan seIama pandemi memberikan dampak pada kecerdasan emosionaI anak usia 5-6 tahun. Kecerdasan emosional anak usia 5-6 tahun memiliki 5 aspek yaitu mengenali emosi diri, mengelola emosi diri, memotivasi diri sendiri, mengenali emosi orang lain dan membina hubungan.

Hasil yang diperoleh menunjukkan bahwa dalam melakukan pembelajaran dalam jaringan selama pandemi memerlukan beberapa faktor yang muncul dari diri anak, orang tua, maupun teknologi yang dimiliki. Anak-anak menjadi kurang mengetahui emosi diri dan mengendalikan emosinya. Terdapat beberapa anak yang sering marah-marah dan mudah menangis. Motivasi dalam melakukan pembelajaran daring pun sangat kurang. Kurangnya berinteraksi dengan teman sebaya maupun orang lain pun membuat anak-anak kurang memahami orang lain serta kurang bersosialisasi.

Pembelajaran dalam jaringan memerlukan penerimaan sikap dalam diri anak, motivasi dari diri anak dan oranglain. Hal ini sejalan dengan Kempt et al. dalam Patricia Aguilera-Hermida (2020) bahwa kontrol perilaku anak selama melakukan pembelajaran dalam jaringan pun sangat diperlukan agar anak dapat mengendalikan emosi dalam dirinya. Proses kognitif dalam diri anakpun sangat diperlukan karena dengan adanya pengetahuan dan kemampuan dari anak akan sangat mempengaruhi proses pembelajaran daring.

Pembelajaran dalam jaringan yang merupakan salah satu kebijakan pemerintah untuk memutus rantai penyebaran covid yang dilakukan di TK sangat memerlukan pantauan dan bimbingan dari orang tua, serta sikap dan motivasi anak yang masih kurang antusias terhadap pembelajaran daring. Berkurangnya intensitas bertemunya anak dengan guru dan teman sebaya pun membuat anak kurang memiliki motivasi untuk mengikuti pembelajaran sehingga cenderung membuat anak untuk menunda-menunda tugas yang diberikan oleh guru. Kesiapan guru Taman Kanak-kanak melakukan pembelajaran daring pada masa pandemi covid-19 ini sangat diperlukan. Persiapan dimulai dari rencana pembelajaran, mengkomunikasikan dengan orang tua, dan fasilitas pendukung lainnya (Ayuni et al., 2021)

Dampak yang diberikan oleh pembelajaran daring selama pandemi terhadap kecerdasan emosionaI anak seperti anak-anak kurang mengetahui dan mengeIola emosi dirinya, kurang dapat memotivasi dirinya sendiri ketika melakukan pembelajaran daing serta kurang mengetahui perasaan orang Iain dan kurang dapat membina hubungan dengan orang Iain dikarenakan anak kurang bersosialisasi dengan orang Iain ketika pembelajaran daring. Orang tua hendaknya memiliki pemahaman mengenai cara belajar anak, membuat 
lingkungan belajar yang kondusif, menentukan jadwal kegiatan yang bersifat fleksibel namun konsisten (Fauziddin et al., 2021). Disamping menjadi pendidik, oraang tua juga menjadi motivator bagi anak (Lilawati, 2020). Meskipun demikian banyak pendidik PAUD yang tidak setuju dengan pembelajaran online karena tidak efektif dan tidak semua orang tua yang memiliki Laptop atau HP untuk pembelajaran online (Nurdin \& Anhusadar, 2020).

Terkait hasiI peneIitian yang diperoleh daIam peneIitian ini, Goleman (2009) menjeIaskan bahwa kecerdasan emosionaI anak merupakan kemampuan untuk memotivasi diri dan bertahan menghadapi frustasi, mengendalikan dorongan hati, dan tidak melebihIebihkan kesenangan, mengatur suasana hati dan menjaga agar beban stres tidak melumpuhkan kemampuan berpikir, berempati, dan berdoa. Dengan seseorang dapat mengetahui keadaan tersebut maka penting bagi seorang individu memiliki kecerdasan emosionaI agar menjadikan hidup Iebih bermakna dan tidak menjaIani hidup dengan sia-sia.

FIP Undiksha (2021) pun menjelaskan bahwa pembelajaran daring membuat anak-anak mudah marah, mudah merasa bosan dan kesepian. EmosionaI anak yang seperti itu dikarenakan suatu bentuk protes dan adaptasi anak yang biasanya anak belajar dan bermain secara Iangsung di sekoIah, ketika pandemi anak harus belajar dan bermain dirumah tanpa bersama guru dan teman-temannya. Anak-anak memerIukan orang Iain untuk menstimulasi kecerdasan emosi nya untuk dapat berinteraksi dengan orang Iain dan menstimulasi kepekaan terhadap perasaan orang Iain.

Faktor adanya hubungan yang antar pembelajaran daIam jaringan selama pandemi juga sejaIan dengan penelitian Aguilera-hermida, (2020) yang menjeIaskan bahwa daIam pembelajaran daIam jaringan selama pandemi terdapat faktor sikap penerimaan anak serta motivasi yang terdapat daIam diri anak. Sikap penerimaan dan motivasi daIam diri anak adaIah salah satu haI yang penting daIam pembeIajaran daring serta erat kaitannya dengan emosionaI anak usia 5-6 tahun.

Kesimpulan daIam penelitian mengenai pembelajaran daIam jaringan selama pandemi dengan kecerdasan emosionaI anak usia 5-6 tahun yaitu memiliki hubungan, namun kedua variabeI ini memiliki tingkat hubungan yang rendah. Pembelajaran daIam jaringan seIama pandemi dapat menimbulkan dampak positif maupun negatif kepada tumbuh kembang anak, saIah satunya yaitu kecerdasan emosionaI anak. PeneIitian ini dapat menjadi pertimbangan oleh guru agar memantau perkembangan anak serta kondisi emosionaI anak usia 5-6 tahun selama pembeIajaran daIam jaringan di masa pandemi.

\section{SIMPULAN}

Pembelajaran dalam jaringan sangat mempengaruhi perkembangan TK terutama dalam emosional anak. Anak mengalami perubahan dalam pengendalian emosi dan proses bersosialisasi dengan orang lain. Berdasarkan hasil dalam penelitian ini disimpulkan bahwa terdapat perubahan kecerdasan emosional anak usia 5-6 tahun dalam melakukan pembelajaran daring selama pandemi.

\section{UCAPAN TERIMA KASIH}

Kami selaku tim peneliti mengucapkan terimakasih kepada pihak TK Gugus Pattimura Mojogedang yang telah berkenan menjadi sumber data serta semua pihak yang telah membantu sehingga penelitian dapat terlaksana dengan lancar.

\section{DAFTAR PUSTAKA}

Aguilera-hermida, A. P. (2020). International Journal of Educational Research Open College students ' use and acceptance of emergency online learning due to COVID-19. International Journal of Educational Research Open, 1(July), 100011. https://doi.org/10.1016/j.ijedro.2020.100011 
Ali, W. (2020). Online and Remote Learning in Higher Education Institutes: A Necessity in light of COVID-19 Pandemic. Higher Education Studies, 10(3), 16. https:// doi.org/10.5539/hes.v10n3p16

Ayuni, D., Marini, T., Fauziddin, M., \& Pahrul, Y. (2021). Kesiapan Guru TK Menghadapi Pembelajaran Daring Masa Pandemi Covid-19. Jurnal Obsesi : Jurnal Pendidikan Anak Usia Dini, 5(1), 414-421. https:// doi.org/10.31004/obsesi.v5i1.579

Azwar, S. (2016). Metode Penelitian. Pustaka Pelajar.

Bowers, J., \& Kumar, P. (2016). Students' perceptions of teaching and social presence: A comparative analysis of face-to-face and online learning environments. In Blended Learning: Concepts, Methodologies, Tools, and Applications (Vol. 4, Issue 1, pp. 15331550). https:// doi.org/10.4018/978-1-5225-0783-3.ch073

Cao, W., Fang, Z., Hou, G., Han, M., Xu, X., \& Dong, J. (2020). The psychological impact of the COVID-19 epidemic on college students in China. Psychiatry Research, 287(March), 112934. https://doi.org/10.1016/j.psychres.2020.112934

Dong, C., Cao, S., \& Li, H. (2020). Children and Youth Services Review Young children ' s online learning during COVID-19 pandemic: Chinese parents ' beliefs and attitudes. Children and Youth Services Review, 118(August), 105440. https:// doi.org/10.1016/j.childyouth.2020.105440

Fauziddin, M., Mayasari, D., \& Rizki, L. M. (2021). Effective Learning for Early Childhood during Global Pandemic. Al-Ishlah: Jurnal Pendidikan, 13(1). https:// doi.org/10.35445/alishlah.v13i1.458

FIP Undiksha. (2021). Anak-Anak Bosan Belajar Daring Saat Pandemi Covid-19, Simak Tipsnya Dari Psikolog Undiksha. FIP Undiksha. http:/ / fip.undiksha.ac.id/anak-anakbosan-belajar-daring-saat-pandemi-covid-19-simak-tipsnya-dari-psikolog-undiksha/

Goleman, D. (2009). Kecerdasan Emosional: mengapa EI lebih penting dari IQ. PT. Gramedia Pustaka Utama.

Hwang, G., Wang, S., \& Lai, C. (2021). Computers \& Education Effects of a social regulationbased online learning framework on students ' learning achievements and behaviors in mathematics. Computers \& Education, 160(August 2020), 104031. https:// doi.org/10.1016/j.compedu.2020.104031

Kemp, S. (2020). Digital 2020: Indonesia. https://datareportal.com/reports/digital-2020indonesia

Lilawati, A. (2020). Peran Orang Tua dalam Mendukung Kegiatan Pembelajaran di Rumah pada Masa Pandemi. Jurnal Obsesi : Jurnal Pendidikan Anak Usia Dini, 5(1), 549. https:// doi.org/10.31004/obsesi.v5i1.630

Mayer, J. D., Salovey, P., \& Caruso, D. R. (2000). Models of emotional intelligence. RJ Sternberg. https:// doi.org/10.1017/CBO9780511807947.019

Mishar, R., \& Bangun, Y. R. (2014). Create the EQ Modelling Instrument Based on Goleman and Bar-On Models and Psychological Defense Mechanisms. Procedia - Social and Behavioral Sciences, 115(Iicies 2013), 394-406. https:// doi.org/10.1016/j.sbspro.2014.02.446

Nurdin, N., \& Anhusadar, L. (2020). Efektivitas Pembelajaran Online Pendidik PAUD di Tengah Pandemi Covid 19. Jurnal Obsesi : Jurnal Pendidikan Anak Usia Dini, 5(1), 686. https://doi.org/10.31004/obsesi.v5i1.699

Patricia Aguilera-Hermida, A. (2020). College students' use and acceptance of emergency online learning due to COVID-19. International Journal of Educational Research Open, 1, 100011. https:// doi.org/10.1016/j.ijedro.2020.100011

Wulandari, H., \& Purwanta, E. (2020). Pencapaian Perkembangan Anak Usia Dini di Taman Kanak-kanak selama Pembelajaran Daring di Masa Pandemi Covid-19. Jurnal Obsesi : Jurnal Pendidikan Anak Usia Dini, 5(1), 452. https:// doi.org/10.31004/obsesi.v5i1.626 